\title{
SGPL1 wt Allele
}

National Cancer Institute

\section{Source}

National Cancer Institute. SGPL1 wt Allele. NCI Thesaurus. Code C105030.

Human SGPL1 wild-type allele is located in the vicinity of $10 \mathrm{q} 21$ and is approximately 65

$\mathrm{kb}$ in length. This allele, which encodes sphing osine-1-phosphate lyase 1 protein, is involved in both the metabolism of phosphorylated sphingoid bases and apoptosis. 